\title{
The impacts of different long-term fertilization regimes on the bioavailability of arsenic in soil: integrating chemical approach with Escherichia coli arsRp::luc-based biosensor
}

\author{
Qi-Hui Hou • An-Zhou Ma • Di Lv • Zhi-Hui Bai • \\ Xu-Liang Zhuang • Guo-Qiang Zhuang
}

Received: 3 December 2013 / Revised: 12 February 2014 / Accepted: 2 March 2014 / Published online: 1 April 2014

(C) Springer-Verlag Berlin Heidelberg 2014

\begin{abstract}
An Escherichia coli arsRp::luc-based biosensor was constructed to measure the bioavailability of arsenic (As) in soil. In previous induction experiments, it produced a linear response $\left(R^{2}=0.96, P<0.01\right)$ to As from 0.05 to $5 \mu \mathrm{mol} / \mathrm{L}$ after a 2 -h incubation. Then, both chemical sequential extraction, Community Bureau of Reference recommended sequential extraction procedures (BCR-SEPs) and E. coli biosensor, were employed to assess the impact of different long-term fertilization regimes containing N, NP, NPK, M (manure), and NPK+ $M$ treatments on the bioavailability of arsenic (As) in soil. Per the BCR-SEPs analysis, the application of M and M+NPK led to a significant $(P<0.01)$ increase of exchangeable As $(2-7$ times and 2-5 times, respectively) and reducible As (1.5-2.5 times and 1.5-2.3 times, respectively) compared with the no fertilization treated soil (CK). In addition, direct contact assay of $E$. coli biosensor with soil particles also supported that bioavailable As in manure-fertilized (M and M+NPK) soil was significantly higher $(P<0.01)$ than that in $\mathrm{CK}$ soil ( 7 and 9 times, respectively). Organic carbon may be the major factor governing the increase of bioavailable As. More significantly, E. coli biosensor-determined As was only $18.46-85.17 \%$ of exchangeable As and 20.68-90.1\% of reducible As based on BCR-SEPs. In conclusion, NKP fertilization was recommended as a more suitable regime in As-polluted soil especially with high As concentration, and this E. coli arsRp::luc-based
\end{abstract}

Qi-Hui Hou and An-Zhou Ma contributed equally to this study.

Q.-H. Hou • A.-Z. Ma ·Z.-H. Bai · X.-L. Zhuang •

G.-Q. Zhuang $(\bowtie)$

Research Center for Eco-Environmental Sciences, Chinese Academy

of Sciences, Shuangqing Road 18, Beijing 100085, China

e-mail: houqihui190@163.com

D. Lv

Insitute of Microbiology, Chinese Academy of Sciences, Beichen

West Road 1, Beijing 100101, China biosensor was a more realistic approach in assessing the bioavailability of As in soil since it would not overrate the risk of As to the environment.

Keywords Long-term fertilization · Arsenic (As) pollution · Bioavailability · Sequential extraction · Microbial biosensor

\section{Introduction}

Arsenic (As) is an odorless and nearly tasteless but toxic natural element. It is classified as one of the most toxic and prioritized pollutants by the WHO and EPA. The permissible level of As in potable water is $10 \mu \mathrm{g} / \mathrm{L}$ for most European countries and the USA (Nordstrom 2002). Inorganic As is a serious human carcinogen, and its accumulation in the body may contribute to the cancer risk of the bladder, liver, kidney, and skin, even at low concentrations (Naujokas et al. 2013). Generally, As contamination originates from its release from the Earth's crust due to a variety of geochemical conditions or microbiological activity (De Brouwere et al. 2004; Dowdle et al. 1996; Nickson et al. 1998). In addition, increasing application of agricultural chemicals, such as fertilizers, organic manure, and pesticides, could also increase the risk of As pollution to farmland and humans (Chirenje et al. 2003; Li et al. 2010; Li and Chen 2005).

To comprehensively imitate the bioavailable metal fraction in soil, kinds of chemical sequential extraction procedures (SEPs) based on a series of selective reagents were widely introduced to clarify the relationship of metal and geochemical phases (Huang and Kretzschmar 2010; Larios et al. 2013; Wenzel et al. 2001). There are different definitions of metal fraction based on different extraction methods, for example, according to a proposal of the European Community Bureau of Reference (BCR), the -acid extractable, -reducible, and oxidizable metal was defined as the SEPs fraction (Rauret 
et al. 1999). Recently, BCR-SEPs were widely used to analyze different metal fractions which could reflect the release of metal from solid-phase soil and metal mobility in soil (Degryse et al. 2009; Giller et al. 2009; Peijnenburg et al. 2007). Although sequential extraction procedures have been popularized in the analysis of metal fractions, it was still criticized because of its low repeatability and representativeness due to the use of different reagents and procedures (Filgueiras et al. 2002; Nolan et al. 2003; Toevs et al. 2006).

It has been reported that chemical extraction may lead to overestimation of the bioavailability of metal in soil. For instance, acetic acid-extracted fraction of cadmium (Cd) was 23 times higher than the microbial biosensor-determined $\mathrm{Cd}$ (Kahru et al. 2005). Bioavailability of $\mathrm{Cu}$ determined by microbial biosensor was tenfold lower than that of acetic acid (Peltola et al. 2005). Microbial biosensor was constituted by a reporter gene and a promoter responsive to metal under the assistance of regulator protein (Harms et al. 2006), and it was another effective approach to assess the bioavailable metal. Numerous microbial biosensors have been applied to detect the bioavailability of metal in polluted water or soil (Bontidean et al. 2004; Liao et al. 2006; Liu et al. 2012) and reflect the toxicity of metal complex to microbes (Campbell et al. 2000; Nybroe et al. 2008). Similarly, several microbial biosensor-based asr operons, which were confirmed as important resistance systems for As and Antimonite ( $\mathrm{Sb}$ ) in E. coli (Ramanathan et al. 1997), have been developed to detect the bioavailability of As (Liao and Ou 2005; Stocker et al. 2003). Compared with chemical sequential extraction methods, microbial biosensor was a less expensive, faster, more convenient, and maneuverable tool to detect metal; what more significant is that it can reflect the actual bioavailability and toxicity of metal (Liao et al. 2006; Stocker et al. 2003; Van Dorst et al. 2010).

Some studies have been focused on the impact of different long-term fertilization regimes on the accumulation of total As and the change in soil properties. For instance, $\mathrm{Li}$ and Chen (2005) found that pig manure could increase As accumulation in soil from 11.8 to $78.9 \mu \mathrm{g} / \mathrm{kg} / \mathrm{year}$ in Beijing, China. However, Li et al. (2010) found that the variation of geological source but not exogenous factors played a more dominant role in determining As concentration in soil. However, the application of long-term fertilization increased organic carbon concentration (Liu et al. 2013; Yang et al. 2011) and the content of phosphorus (P) (Ge et al. 2008; Zheng et al. 2008a) and changed the acidity of soil depending on the soil conditions (Dong et al. 2012; Zheng et al. 2008b). Meanwhile, the release of metal including As from the solid phase of soil was influenced by organic carbon based on the formation of soluble metal-organic complexes (Cao et al. 2003; Grafe et al. 2002; Harvey et al. 2002; Jackson et al. 2006; Mladenov et al. 2010; Wang and Mulligan 2006). pH and $\mathrm{P}$ also have been confirmed as major factors impacting the release of As by the mechanism of competitive anion exchange (De Brouwere et al. 2004; Grafe et al. 2002; Signes-Pastor et al. 2007; Wang and Mulligan 2006; Yang et al. 2002; Zhao and Stanforth 2001).

Assessing the bioavailability of As in agricultural soil is significant as the bioavailability of As reflects the actual environmental risk and the security of agricultural products. Different long-term fertilization regimes could lead to a great change of the soil physical and biochemical characteristics such as organic carbon, pH, and P (Ge et al. 2008; Liu et al. 2013; Yang et al. 2011; Zheng et al. 2008a), which may cause variation of bioavailable As. There is scant comprehensive research about the impact of long-term fertilization containing $\mathrm{N}, \mathrm{NP}, \mathrm{NPK}, \mathrm{M}$ (manure), and NPK $+\mathrm{M}$ on the bioavailable As in soils. In this research, in order to provide an accurate and complete assessment about the impact of long-term agricultural regimes (N, NP, NPK, M, NPK $+\mathrm{M}$ ) on the environmental risk of As, both chemical BCR-SEPs and regulator gene arsR-based E. coli biosensor were employed to assess the bioavailability of As. The followings were addressed: (i) the relationships between bioavailable fractions of As and different fertilization regimes in soil, (ii) the intrinsic factors that affect the bioavailability of As, and (iii) the comparison between BCR-SEP- and biosensor-determined bioavailability of As.

\section{Materials and methods}

\section{Site description}

The soil samples were collected from Qiyang $\left(111^{\circ} 53^{\prime} \mathrm{E}, 26^{\circ} 4^{\prime}\right.$ N) agricultural experimental stations, located at Taoyuan County of Hunan Province. These samples are typical red soil (45.0\% clay, $46.3 \%$ silt, and $8.7 \%$ sand). The long-term fertilization experiment in the paddy field was initiated in 1990. The applied amounts of chemical fertilizers were as follows: $160.0 \mathrm{~kg} \mathrm{~N} \mathrm{hm}^{-2}$ year $^{-1}$ urea, $35.0 \mathrm{~kg} \mathrm{P} \mathrm{hm}^{-2}$ year $^{-1}$ super phosphate, and $49.8 \mathrm{~kg} \mathrm{~K} \mathrm{hm}^{-2}$ year $^{-1}$ potassium chloride. The amount of organic fertilization was $22,500 \mathrm{~kg} \mathrm{hm}^{-2} \mathrm{year}^{-1}$.

Samples treatment and characteristics analysis

Six typical soil samples with different fertilization treatments (Table 1) were collected (depth $0-20 \mathrm{~cm}$ ) by the principle of five-site mixing. Before analyzing the physical and chemical properties of the soil samples, the samples were air-dried and passed through a 2-mm sieve. The basic chemical characteristics of the soil samples are listed in Table 1. The amounts of organic carbon (C), cation exchange capacity (CEC), and total $\mathrm{N}$ were determined at the Institute of Agricultural Resources and Regional Planning, Chinese Academy of Agricultural Sciences. Soil $\mathrm{pH}$ was determined with Mettler Toledo FE20 FiveEasy ${ }^{\mathrm{TM}} \mathrm{pH}$ meter (USA) at a soil to water ratio of 1:2.5. 
Table 1 Characteristics of soil samples

\begin{tabular}{lllllllc}
\hline Fertilization $^{\mathrm{a}}$ & $\mathrm{pH}($ water$)$ & Organic C $(\mathrm{g} / \mathrm{kg})$ & $\mathrm{CEC}(\mathrm{cmol}(+) / \mathrm{kg})$ & Total N $(\mathrm{g} / \mathrm{kg})$ & Total As $(\mathrm{mg} / \mathrm{kg})$ & Total Sb $(\mathrm{mg} / \mathrm{kg})$ & Total Cd $(\mathrm{mg} / \mathrm{kg})$ \\
\hline $\mathrm{CK}$ & $5.58 \pm 0.03$ & $8.24 \pm 0.33$ & $10.01 \pm 0.05$ & $1.12 \pm 0.08$ & 45.30 & 8.69 & 1.82 \\
$\mathrm{~N}$ & $4.32 \pm 0.06$ & $8.95 \pm 0.02$ & $9.12 \pm 0.01$ & $1.10 \pm 0.06$ & 43.72 & 7.22 & 0.79 \\
$\mathrm{NP}$ & $4.25 \pm 0.08$ & $11.12 \pm 0.10$ & $9.64 \pm 0.01$ & $1.15 \pm 0.05$ & 50.21 & 1.78 & 1.41 \\
$\mathrm{NPK}$ & $4.42 \pm 0.05$ & $11.61 \pm 0.04$ & $9.65 \pm 0.01$ & $1.18 \pm 0.11$ & 52.42 & 10.95 & 1.70 \\
$\mathrm{M}$ & $6.68 \pm 0.04$ & $16.89 \pm 0.22$ & $12.29 \pm 0.02$ & $1.47 \pm 0.03$ & 47.12 & 3.73 & 15.64 \\
$\mathrm{NPK}+\mathrm{M}$ & $5.80 \pm 0.08$ & $18.64 \pm 0.07$ & $10.15 \pm 0.01$ & $1.39 \pm 0.04$ & 46.44 & 8.31 & 8.85
\end{tabular}

${ }^{\mathrm{a}} \mathrm{CK}$ represents unfertilized (control) treatment; N, P and K represent chemicals nitrogen, phosphorus, and potassium fertilizers, respectively; M represents manure

The digestion of total As was carried out by aqua regia $(\mathrm{HCl} /$ $\mathrm{HNO}_{3}=3: 1$ in $\left.v / v\right)$ and $\mathrm{HClO}_{4}$. Total As concentration of digested solution was detected by Inductively coupled plasma mass spectrometry (ICP-MS, Agilent, USA).

\section{Addition experiment and BCR-SEPs analysis of As}

To assess the impact of different long-term fertilization regimes on the bioavailability of As at different pollution levels, liquid As solution (sodium arsenite) was added to $50-\mathrm{mL}$ centrifuge tubes at levels of 0,50 , and $100 \mathrm{mg} \mathrm{As} / \mathrm{kg}$ dry soil (water/dry soil=1:1 in $w / w$ ), and all treatments were carried out in triplicate. The centrifuge tubes were then left open and equilibrated at room temperature for 60 days. After equilibration, the air-dried soil was grinded completely, and the As fractions in different fertilization-treated soils were analyzed by optimized BCR-SEPs as follows (Ure et al. 1993): the acidextractable fraction of As (F1) was leached from $1 \mathrm{~g}$ of soil by $0.11 \mathrm{M}$ acetic acid, the reducible fraction of As (F2) was extracted from the residue of $\mathrm{F} 1$ with $0.1 \mathrm{M}$ hydroxylamine hydrochloride, the oxidizable fraction of As was liberated from the residue of $\mathrm{F} 2$ by $8.8 \mathrm{M}$ hydrogen peroxide and $1 \mathrm{M}$ ammonium acetate, and the last residual fraction of As (F4) was digested with aqua regia and perchloric acid mixture according to the aforementioned procedure for total As analysis. Total As concentrations in the four fractions were also determined by ICP-MS (Agilent, USA).

\section{Construction and induction of $E$. coli arsRp::luc-based} biosensor

The plasmid parsRluc of the E. coli arsRp::luc-based biosensor was developed from the elementary plasmid frame pUC18luc, which can efficiently express the luminescence reporter gene $l u c$ of commercial plasmid pGEM-luc (Promega, USA; GenBank accession number X65316) at the T7 promoter (Hou et al. 2013). For the construction of parsRluc, a cloned fragment containing the regulatory gene $\operatorname{ars} R$ (GenBank accession number NC 000913) and its promoter Pars was amplified (forward primer 5'GATCGAGCTC TTACCTTCCTCTGCACTTAC3'; reverse primer: 5'CCGC
TCGAGTTAACTGCAAATGTTCTTACTGTCCCC3') from the As resistance system of plasmid R773 of E. coli K-12 (Biomed, China). The T7 promoter of pUC18luc was then replaced by arsR and its promoter fragment Pars (Fig. 1).

Induction assays of $E$. coli biosensor harboring parsRluc by standard As solutions (sodium arsenite) were performed as follows: a single colony of $E$. coli biosensor cells was cultured while shaking $\left(200 \mathrm{rpm} / \mathrm{min}, 37^{\circ} \mathrm{C}\right)$ in $50 \mathrm{~mL}$ Luria-Bertani (LB) medium containing $100 \mu \mathrm{g} / \mathrm{mL}$ ampicillin for $16 \mathrm{~h}$. Then, $400 \mu \mathrm{L}$ culture solution was added to $20 \mathrm{~mL}$ fresh $\mathrm{LB}$ (ampicillin $100 \mu \mathrm{g} / \mathrm{mL}$ ) and incubated with shaking $(200 \mathrm{rpm} /$ min) at $37^{\circ} \mathrm{C}$ until the $O D_{600 \mathrm{~nm}}$ reached $0.6-0.8$. The cell culture was then diluted to an $O D_{600}$ of 0.2 with fresh LB medium. For the induction of the luminescence signal, $50 \mu \mathrm{L}$ of various concentrations of As standard solution ( 0.05 to $50 \mu \mathrm{M}$ ) in Milli-Q water was added to 96-well cell culture clusters (Costar, USA), and an equal volume of diluted bacterial culture was added. The mixed solutions were incubated in a Thermo Shaker Incubator (Thermo, Finland) at $30{ }^{\circ} \mathrm{C}$ (200 rpm/min) for $2 \mathrm{~h}$.

After incubation, E. coli biosensor cells were lysed by the E1500 luciferase assay system (Promega, USA), and the luminescence signal was detected by Glomax-Muti+ Microplate Multimode Reader (Promega, USA) according to the supplier's instructions. At least three independent experiments were conducted in this process.

Determination of bioavailable As by E. coli arsRp::luc-based biosensor

To assay the total As in soil-water extracts and bioavailable As in soil-water suspensions, soil-water extracts and soil-water suspensions were prepared as follows: $1 \mathrm{~g}$ air-dried soil was mixed with $9 \mathrm{~mL}$ demonized water in $50 \mathrm{~mL}$ centrifuge tubes (Corning, USA). The suspensions were completed by shaking the water-soil mixture for $24 \mathrm{~h}$ at $25^{\circ} \mathrm{C}$. The suspensions were centrifuged at 16,000 $\mathrm{g}$ for $5 \mathrm{~min}$ (Ivask et al. 2004), and the supernatants were then gathered as soil-water extracts. The total As in soil-water extracts was determined by ICP-MS 
Fig. 1 Construction of E. coli arsRp::luc-based biosensor

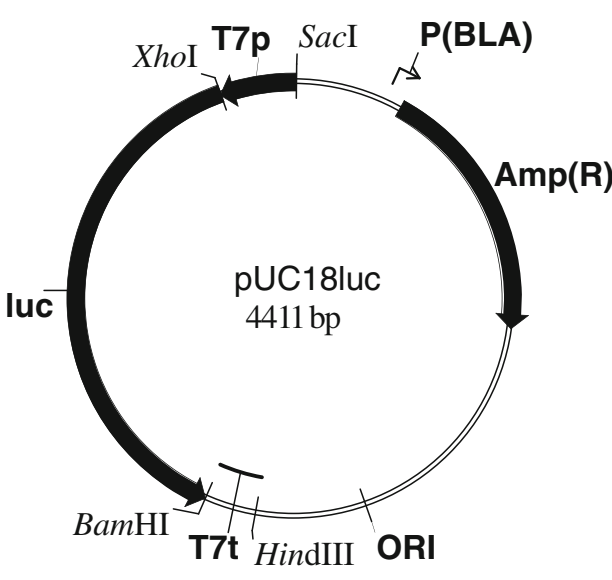

(Agilent, USA). The bioavailable As in soil-water suspensions was determined by E. coli biosensor harboring parsRluc.

Before the induction experiments, 50 or 100 times serial dilutions of the soil-water suspensions were prepared with water according to the concentrations of As in soil-water extracts. In order to avoid the significant influence $(P>0.05)$ of impurity or particles on the emission of luminescence, E. coli $\mathrm{DH} 5 \alpha$ containing plasmid pUC18NLR (our laboratory) which can constitutively express $l u c$ under the regulation of $n p t I I$ promoter was set as positive control. Final results were from three independent experiments.

\section{Results}

Dose response of E. coli arsRp::luc-based biosensor

After a series of molecular operations, a $E$. coli biosensor (deposited in our laboratory) containing 4,631 bp-plasmid parsRluc was constructed to determine the bioavailability of As in polluted environments. The response characteristic to different doses of As solution was tested after $2 \mathrm{~h}$ of induction. Results showed (Fig. 2) that the relative luminescence unit (RLU) presented a positive trend with the rising of As dose from 0.05 to $10 \mu \mathrm{M}$. RLU decreased rapidly when the As dose was more than $10 \mu \mathrm{M}$, probably due to the toxic effects of As on the biosensor cells. In this study, the statistically significant $(P<0.05$, the significance analysis in this research was tested by ANOVA based on the Microsoft Origin 8.0) limit of detection (LOD) of the biosensor to As was $0.1 \mu \mathrm{M}$. Regression analysis indicated a more linear relationship $\left(R^{2}=0.96\right.$, correlation analysis in this research was conducted by linear regression based on the Microsoft Origin 8.0) between the RLU and As concentration from 0.05 to $5 \mu \mathrm{M}$, in which range the As concentration could be quantified by this biosensor.
Bioavailability of As in soil treated with different fertilizations based on BCR-SEPs

Results (Fig. 3) showed that, compared with the soil samples treated with different fertilization regimes, the CK soil possessed the lowest F1 fraction (exchangeable As) and F2 fraction (reducible As) at all the three As addition levels, and statistical analysis indicated that the F1 fraction in CK soil was significantly lower than that in soil treated with manure containing $\mathrm{M}$ and NPK $+\mathrm{M}(P<0.05)$. Further, the F2 fraction in CK soil was significantly lower than that in the other five fertilization-treated soils. On contrary, the CK soil had the highest F4 fraction (inactive As) at all the three As addition levels, and it was significantly higher than that in soil treated with NP, M, and NPK + M $(P<0.05)$. The F3 fraction (oxidizable As) in $\mathrm{CK}$ soil had no obvious difference with other five soils treated with different fertilization.

In all fertilization-treated soil, the active As (F1 and F2 fractions) gradually increased while the inactive As (F4 fraction) gradually decreased with the increase of spiked As from 0 to $100 \mathrm{mg} / \mathrm{kg}$. Moreover, the application of manure

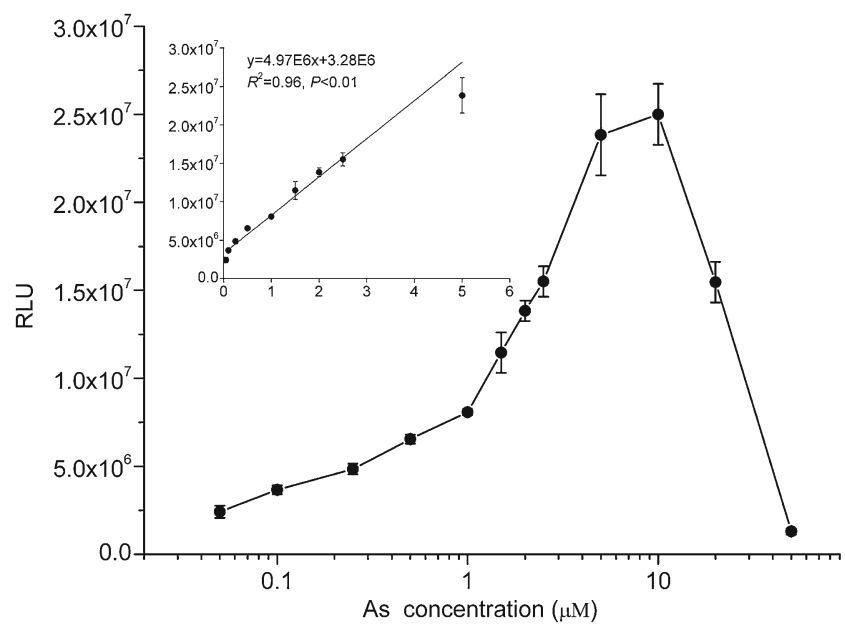

Fig. 2 Dose-dependent induction of $E$. coli biosensor harboring parsRluc and its corresponding linear regression 

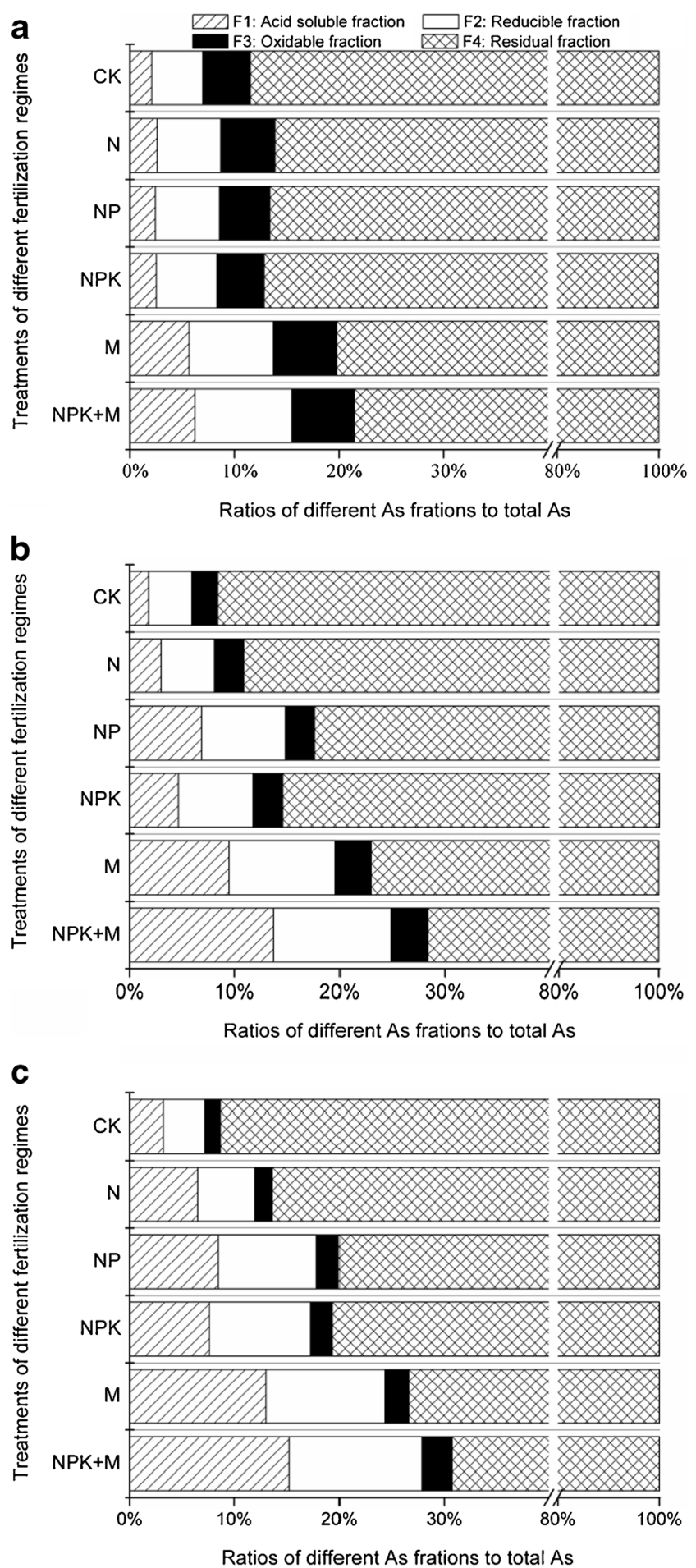

Fig. 3 Ratios of As fraction-based BCR-SEPs in soil under different fertilization regimes. a $0 \mathrm{mg} / \mathrm{kg}$ As addition, b $50 \mathrm{mg} / \mathrm{kg}$ As addition, c $100 \mathrm{mg} / \mathrm{kg}$ As addition

fertilization indicated a more obvious effect on F1 and F2 fractions. The application of NPK $+\mathrm{M}$ increased F1 fraction from 4.13 to $14.93 \%$ and $\mathrm{F} 2$ fraction from 4.39 to $8.63 \%$ compared with the CK soil. Similarly, M treatment also increased $\mathrm{F} 1$ fraction from 3.58 to $10.02 \%$ and $\mathrm{F} 2$ fraction from 3.18 to $7.25 \%$ compared with the CK soil. The increase of F1 fraction in NPK $+\mathrm{M}$ and M-treated soils was significantly higher $(P<0.05)$ than the other treatments $(\mathrm{N}[0.52$ to $3.30 \%$ ], NP $[0.35$ to $5.30 \%]$, and NPK [ 0.44 to $4.44 \%]$ ). The increase of $\mathrm{F} 2$ fraction in NPK $+\mathrm{M}$ and M-treated soils was also significantly higher $(P<0.05)$ than that in the other treatments (N [1.00 to $1.50 \%$ ], NP [1.28 to $5.37 \%$ ], and NPK [0.95 to $5.68 \%])$. In general, the application of N, NP, NPK, M, and NPK + M could all promote the transformation of As from the residual fraction (F4) to the relative active fractions (F1 and F2), and the M and NPK + M treatments exhibited a more obvious role. Transformation efficiency of F4 fraction to F1 and F2 fractions followed the order NPK $+\mathrm{M}>\mathrm{M}>\mathrm{NP}>$ NPK $>\mathrm{N}$ (except for the treatment of $0 \mathrm{mg} / \mathrm{kg}$ additional As which followed $\mathrm{N}>\mathrm{NP}>\mathrm{NPK}$ ).

The As recovery ratio of BCR-SEPs ranged from 91.34 to $99.52 \%, 90.78$ to $102.80 \%$, and 90.27 to $93.59 \%$ at 0,50 , and $100 \mathrm{mg} / \mathrm{kg}$ addition levels of As, respectively, which showed completely acceptable quality control of As in this sequential extraction procedure (Van Herreweghe et al. 2003).

Bioavailability of As in soil treated with different fertilization based on E. coli biosensor

In consideration of the possible interference of arsenate and organic As in natural soils, bioavailable As described in this research based on biosensor was expressed as an equivalent concentration including arsenate and organic As. A direct contact assay of E. coli arsRp::luc biosensor cells with soil particles in soil-water suspensions indicated that the bioavailability of As in soil-water suspensions was significantly higher $(P<0.05,4.0-10.0$ times, Table 2$)$ than the total As in soil-water solution, and it was in accord with these reports which have showed that the direct contact assay could reflect more bioavailable metal than soil-water extract (Ivask et al. 2002, 2004). The increase of As addition levels from 0 to $100 \mathrm{mg} / \mathrm{kg}$ in M- and NPK + M-treated soils have 7 and 11 times, respectively, the accumulation of bioavailable As in soil-water suspensions compared with CK soil. At $50 \mathrm{mg} / \mathrm{kg}$ As addition level, the concentrations of bioavailable As in soil-water suspensions of different fertilization-treated soil are as follows: NPK $+M>M>N P$, and $M$ and NPK $+M$ treatments were, respectively, 4.0- and 5.0-times higher than the NP-treated soil. At $100 \mathrm{mg} / \mathrm{kg}$ As addition level, the concentrations of bioavailable As in soil-water suspensions are as follows: NPK $+\mathrm{M}>\mathrm{NP}>\mathrm{N}>\mathrm{NPK}$, and bioavailable As in M- and NPK + M-treated soils was 4.0-7.0 times and 5.0-9.0 times, respectively, more than that in N-, NP-, and NPK-treated soils (Table 2). In summary, soil-water suspensions could reflect significantly more bioavailable As than in a soil-water solution by biosensor, and the application of manure fertilization ( $\mathrm{M}$ and $\mathrm{M}+\mathrm{NPK}$ ) may enhance the bioavailability of As in soil (7.0 and 9.0 times, respectively) compared with CK soil. NKP fertilization was recommended 
Table 2 Detection of total As in soil-water solution and bioavailable As in soil-water suspensions of different fertilizations-treated soil samples

\begin{tabular}{|c|c|c|c|c|c|c|}
\hline \multirow[t]{2}{*}{ Fertilization (natural As, mg/kg) } & \multicolumn{2}{|l|}{0 addition } & \multicolumn{2}{|c|}{$50 \mathrm{mg} / \mathrm{kg}$ addition } & \multicolumn{2}{|c|}{$100 \mathrm{mg} / \mathrm{kg}$ addition } \\
\hline & $\begin{array}{l}\text { water } \\
\text { soluble As } \\
(\mathrm{mg} / \mathrm{kg})\end{array}$ & $\begin{array}{l}\text { biosensor- } \\
\text { determined } \\
\text { As }(\mathrm{mg} / \mathrm{kg})\end{array}$ & $\begin{array}{l}\text { water } \\
\text { soluble As } \\
(\mathrm{mg} / \mathrm{kg})\end{array}$ & $\begin{array}{l}\text { biosensor- } \\
\text { determined } \\
\text { As }(\mathrm{mg} / \mathrm{kg})\end{array}$ & $\begin{array}{l}\text { water } \\
\text { soluble As } \\
(\mathrm{mg} / \mathrm{kg})\end{array}$ & $\begin{array}{l}\text { biosensor- } \\
\text { determined } \\
\text { As }(\mathrm{mg} / \mathrm{kg})\end{array}$ \\
\hline CK (45.30) & $0.01 \pm 0.00$ & ND & $0.04 \pm 0.00$ & ND & $0.07 \pm 0.00$ & ND \\
\hline $\mathrm{N}(43.72)$ & $0.01 \pm 0.00$ & ND & $0.06 \pm 0.00$ & ND & $0.15 \pm 0.01$ & $1.58 \pm 0.30$ \\
\hline $\mathrm{NP}(50.21)$ & $0.01 \pm 0.00$ & ND & $0.24 \pm 0.00$ & $1.53 \pm 0.54$ & $0.35 \pm 0.03$ & $2.63 \pm 0.54$ \\
\hline NPK(52.42) & $0.01 \pm 0.00$ & ND & $0.09 \pm 0.02$ & ND & $0.26 \pm 0.03$ & $2.73 \pm 0.41$ \\
\hline $\mathrm{M}(47.12)$ & $0.28 \pm 0.03$ & $1.62 \pm 0.18$ & $1.29 \pm 0.08$ & $7.24 \pm 0.59$ & $2.76 \pm 0.09$ & $12.38 \pm 0.49$ \\
\hline $\mathrm{NPK}+\mathrm{M}(46.44)$ & $0.25 \pm 0.02$ & $1.32 \pm 0.09$ & $1.73 \pm 0.07$ & $8.46 \pm 1.00$ & $3.26 \pm 0.14$ & $15.49 \pm 1.45$ \\
\hline
\end{tabular}

ND not determined

as a more suitable regime in As-polluted agricultural soil, especially with high As concentration, because of its slight impact on the bioavailability of As and complete nutrition to plant.

\section{Discussion}

Application of biosensor to assess the bioavailable As in different long-term fertilizations-treated soils

The application of different long-term fertilization regimes could lead to a great change of soil characteristics, such as levels of organic C, P, and the $\mathrm{pH}$ (Dong et al. 2012; Ge et al. 2008; Liu et al. 2013; Yang et al. 2011; Zheng et al. 2008a, b), which could affect the fraction and bioavailability of metal in soil, thereby posing risk to agricultural products. Sequential chemical extraction does not represent the actual bioavailability of As in soil. Therefore, to accurately assess the impacts of different long-term fertilization regimes ( $, N P, N P K, M$, MINK) on the bioavailability of As in soil, an arsRp::lucbased $E$. coli biosensor was constructed and applied in this research, as well as a chemical BCR-SEPs method.

The reporter gene is an important factor that can affect the sensitivity of biosensor. In this research, luc was employed as the reporter gene because of its high sensitivity and rapid response characteristics (Billard and DuBow 1998; Hakkila et al. 2002). Experiments showed that after a 2-h induction, the biosensor produced an obvious increase of RLU at $0.05 \mu \mathrm{M}$ As (LOD), which was below the WHO permissible level of $10 \mu \mathrm{g} / \mathrm{L}$ (equivalent to $0.13 \mu \mathrm{M}$ ) in potable water (Nordstrom 2002). In addition, other factors such as the host strain, concentration of host strain, culture medium, and $\mathrm{pH}$ could also affect the LOD of a biosensor (Golding et al. 2008; Rasmussen et al. 1997; Riether et al. 2001; Tauriainen et al. 1998).

The water-soluble metal represented the most free and bioavailable relevant metal fraction (Giller et al. 2009; Peijnenburg and Jager 2003; Worms et al. 2006). However, direct contact assay of biosensor with soil particles could reflect a distinctly higher level of bioavailable $\mathrm{Cd}$ (20- or 115-fold), $\mathrm{Hg}$ (30-fold), and $\mathrm{Pb}$ (40-fold) than soil-water extract assay (Ivask et al. 2002, 2004). Therefore, the direct contact assay was essential to assess the bioavailability of metals for biosensor, although the mechanisms involving the increase of bioavailable metals in direct contact assay are still not clear. Our result also showed that the bioavailability of As in soil-water suspensions was significantly higher (4 to 10 times) than the total As in soil-water extracts. It is in accordance with the research of Ivask et al. (2007), in which they found that fourfold more As was available to nonimmobilized sensor bacteria. However, this result is inconsistent with the finding of Petanen and Romantschuk (2003), which indicated that there was no obvious difference of bioavailable As between the water-extractable fraction and soil-water slurry. The different characteristics of biosensor strain and soil sample may be major factors that led to the discrepant result.

Factors governing the difference of bioavailable As

Both BCR-SEPs and arsRp::luc-based E. coli biosensor indicated that the application of all the fertilization treatments containing N, NP, NPK, M, and NPK + M could lead to an increase of bioavailable As in soil, and more importantly, manure fertilization ( $\mathrm{M}$ and NPK $+\mathrm{M}$ ) has showed a more obvious impact. Moreover, the more active the As was, the more easily it was released from the treated soil. In this research, water-soluble As in soil treated with NPK $+\mathrm{M}$ and $\mathrm{M}$ fertilizations was at least 25 times higher than that in $\mathrm{CK}$ soil (Table 2). Even without addition of As, the final concentration of water-soluble As in NPK + M and M fertilizationtreated soils exceeded the safe value for drinking water as recommended by WHO $(10 \mu \mathrm{g} / \mathrm{L})$.

Several factors may contribute to this result. It has been reported that the application of inorganic or organic fertilizers can increase the content of organic carbon in soil and maintain soil productivity (Liu et al. 2013; Yang et al. 2011). Additionally, it has been confirmed that As mobilization is associated with the concentration of dissolved organic carbon 


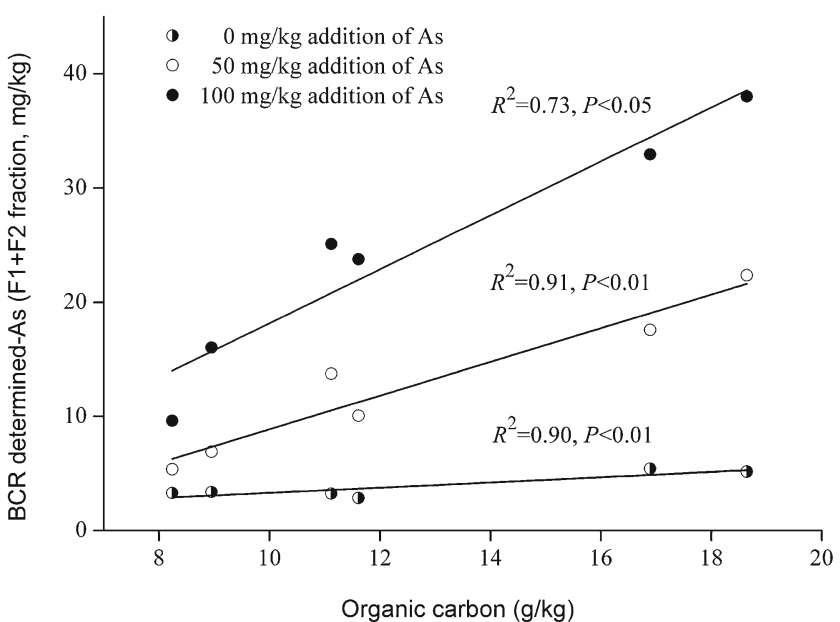

Fig. 4 Correlation analysis of BCR-SEPs-determined As (F1+F2) and organic carbon in soil

in soil, which is due to the organic ligands of dissolved organic carbon (DOC) that facilitate the release of inactive As (F4 fraction) to active soluble As (F1 fraction) through competitive sorption or through solution complexation (Cao et al. 2003; Harvey et al. 2002; Jackson et al. 2006; Mladenov et al. 2010). In addition, $\mathrm{Fe}$ oxyhydroxides precipitated by microbes have a strong adsorption capacity to As in soil (Harvey et al. 2002; Mladenov et al. 2010; Yang et al. 2002); Consequently, the enhancement of soluble As could also lead to an increase of As bound to Fe oxyhydroxides which belonged to $\mathrm{F} 2$ fraction of As . Given that the organicbound As was negligible in polluted soil (Sarkar et al. 2007), only exchangeable As (F1 fraction) and Fe-Mn-oxide-bound As (F2 fraction) were considered to be potential bioavailable As as determined by BCR-SEPs in this research. Our investigation also found that the application of inorganic or organic fertilizers increased the content of organic carbon from 8.24 to $18.64 \mathrm{mg} / \mathrm{kg}$ (Table 1), and statistical results showed that the concentration of potential bioavailable As $(\mathrm{F} 1+\mathrm{F} 2)$ was

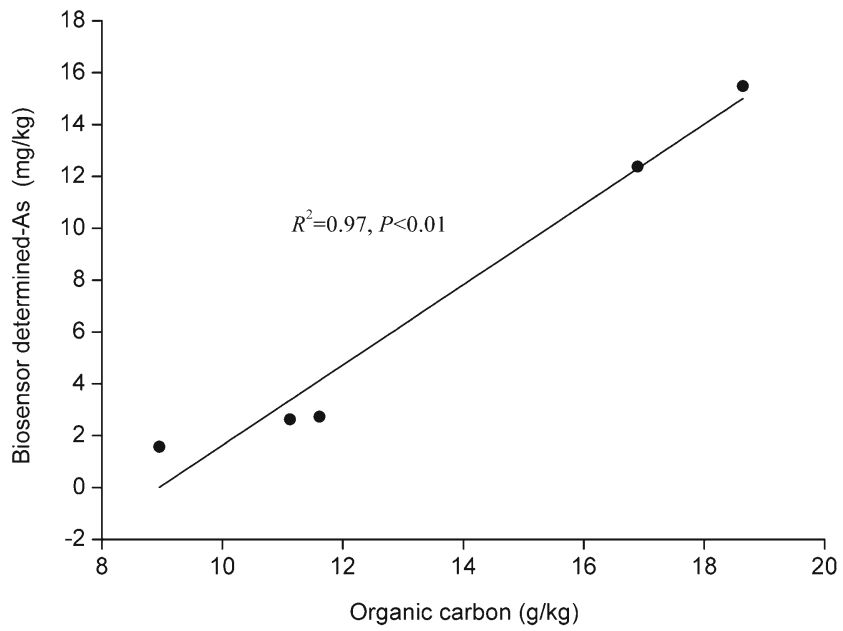

Fig. 5 Correlation analysis of biosensor-determined As and organic carbon in soil at $100 \mathrm{mg} / \mathrm{kg}$ As addition level

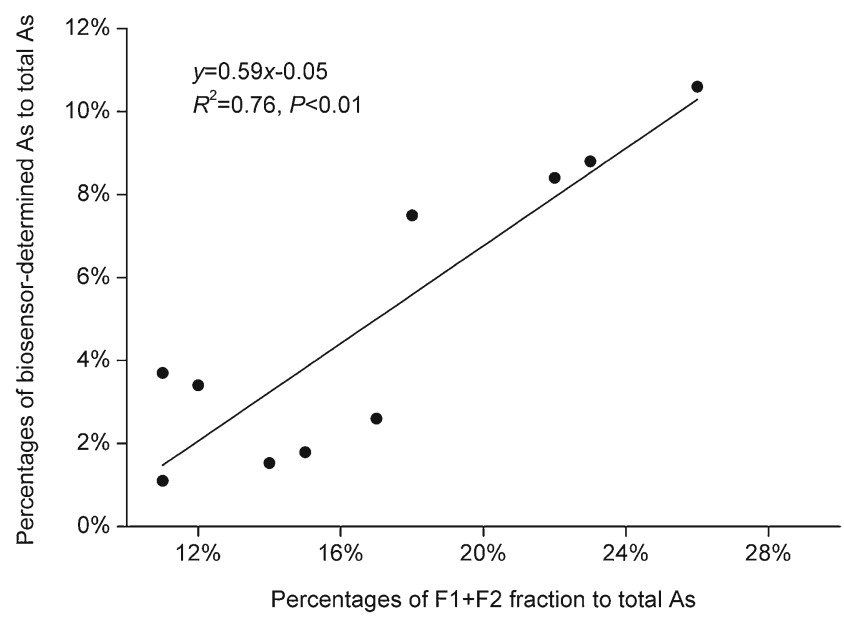

Fig. 6 Correlation analysis of BCR-SEP-determined As (F1 + F2) and biosensor-determined As

positively correlated with organic carbon at all addition levels of As (Fig. 4), and the correlation coefficients were 0.73 $(P<0.05), 0.91(P<0.01)$, and $0.90(P<0.01)$, respectively, from low to high As concentrations. These results were similar with those of Jackson et al. (2006) and Kalbitz and Wennrich (1998), in which they found a positive correlation between DOC and soluble As concentrations.

Similarly, biosensor-determined As was linearly correlated $\left(R^{2}=0.96, P<0.01\right)$ with the content of organic carbon in soil at $100 \mathrm{mg} / \mathrm{kg}$ As addition level (Fig. 5). Although the mechanism of how the biosensor cells adsorb As in soil-water suspension is yet to be elucidated, the increase of active As and the decrease of inactive As were undoubtedly the most crucial reason that led to a significant increase of bioavailable As in NPK + M- and M-treated soils.

It has been indicated that organic carbon could lead to the rise of the mobile and soluble As (Cao et al. 2003; Harvey

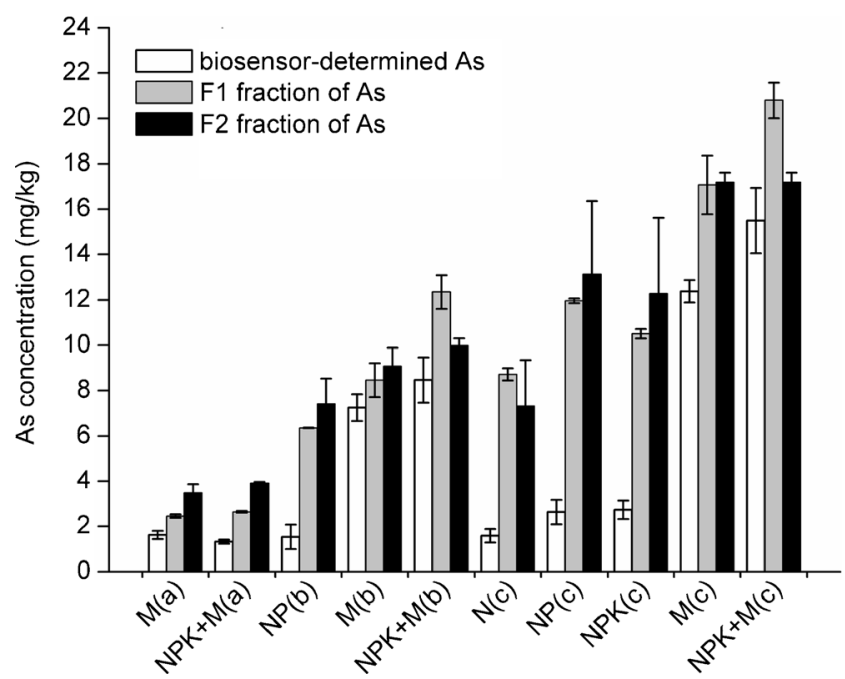

Fig. 7 Comparison of BCR-SEPs-determined As (F1, F2) with the biosensor-determined As at the three As addition levels: $0 \mathrm{mg} / \mathrm{kg}$, $50 \mathrm{mg} / \mathrm{kg}$, and $100 \mathrm{mg} / \mathrm{kg}$ 
et al. 2002; Jackson et al. 2006; Mladenov et al. 2010). Although there is no direct conclusion to prove that As bound with organic carbon is available by biosensor cell, however, interactions between organic carbon and As can be influenced by various factors such as $\mathrm{pH}$, redox potential, and other competing ions in aquatic environments, and it could cause the secondary release of As to aquatic environments and the rise of bioavailable As (Wang and Mulligan 2006).

$\mathrm{pH}$ and $\mathrm{P}$ were important direct factors governing the mobility of As in soil. It has been reported that sequestration of As from of Fe-Mn oxides of mineral surfaces was consistently increasing with lower $\mathrm{pH}$ (Signes-Pastor et al. 2007; Wang and Mulligan 2006; Yang et al. 2002), because low pH values could lead to the formation of more positively charged Fe oxides, and then positively charged Fe oxides could adsorb more As anions on the mineral surface (Lafferty and Loeppert 2005; Jain et al. 1999). In this research, NPK + M and M treatments have led to a slight increase of $\mathrm{pH}$, but other treatments were opposite. Therefore, $\mathrm{pH}$ may have partly contributed to the difference of bioavailable As in differently treated soil. Although there was no investigation on $\mathrm{P}$ after treatments, the application of NP, NPK, and NPK + M regimens undoubtedly led to an increase of $\mathrm{P}$ content (Zheng et al. 2008a; Ge et al. 2008). Meanwhile, P in fertilization may be another factor affecting the release of As due to its similar chemical properties to As and its competitive sorption with As in the soil matrix (De Brouwere et al. 2004; Signes-Pastor et al. 2007; Zhao and Stanforth 2001).

\section{Comparison of BCR-SEPs-determined As}

with biosensor-determined As

Statistical analysis showed a correlation $\left(R^{2}=0.76, P<0.01\right)$ between BCR-SEPs-determined As (F1 and F2 fractions) and biosensor-determined As (Fig. 6). It manifested BCR-SEPs and biosensor presented relative consistently to assess the active As and inactive As, and it was similar with the result of Tibazarwa et al. (2001), in which they found a correlation $\left(R^{2}=0.96\right)$ between Ralstonia eutropha biosensor-determined and $\mathrm{Ca}\left(\mathrm{NO}_{3}\right)_{2}$-extractable $\mathrm{Ni}$.

However, biosensor-determined As was only 50 to $66.12 \%(0 \mathrm{mg} / \mathrm{kg}$ As addition level), 24.13 to $85.17 \%$ $(50 \mathrm{mg} / \mathrm{kg}$ As addition level), and 18.46 to $70.1 \%(100 \mathrm{mg} /$ $\mathrm{kg}$ As addition level) of F1 fraction of As. Similarly, biosensor-determined As was only 34.02 to $43.2 \%$ (0 mg/ $\mathrm{kg}$ As addition level), 20.68 to $84.61 \%(50 \mathrm{mg} / \mathrm{kg}$ As addition level), and 20.03 to $84.24 \%$ (100 mg/kg As addition level) of F2 fraction of As (Fig. 7). These results indicated that BCRSEPs-determined As (F1 and F2 fractions) was not completely bioavailable by the $E$. coli biosensor cells, and it was only a potential available fraction that could be transformed to instantly bioavailable As during the variations of the soil environment.
The main reason may be because most of the exchangeable As and reducible As (such as Fe-Mn oxides) were unavailable instantly to $E$. coli biosensor even though the direct contact assay was introduced in this research. The result was consistent with these in which chemical extractions have overestimated the bioavailability of $\mathrm{Cd}$ by 23 times (Kahru et al. 2005) and $1 \mathrm{M} \mathrm{NaOAc}$-estimated $\mathrm{Pb}$ was four times higher than the bioavailable $\mathrm{Pb}$ judged by biosensor (Peltola et al. 2005).

The variation of environmental factors may lead to the transformation of As from potential available form to actual bioavailable form. For instance, The lower Eh (redox potential) could cause the dissolution of Fe oxide (F2 fraction) crystallized from soil and lead to the release and desorption of As bound with $\mathrm{Fe}$ oxide (Xu et al. 2011). The abovementioned $\mathrm{pH}$, organic $\mathrm{C}, \mathrm{P}$, and other factors such as electrical conductivity (EC) and saline ion fluctuation (Sarkar and Datta 2003, 2004) could also contribute to the transformation of As to bioavailable form. Based on this result, E. coli biosensor was recommended as a more realistic approach in assessing the bioavailability of As in soil because it would not overestimate the current risk of As to the environment.

Acknowledgments This work was supported by the National Key Technology R\&D Program (2012BAJ24B01). We are grateful to the anonymous reviewers for their helpful comments on the manuscript.

\section{References}

Billard P, DuBow MS (1998) Bioluminescence-based assays for detection and characterization of bacteria and chemicals in clinical laboratories. Clin Biochem 31:1-14

Bontidean L, Mortari A, Leth S, Brown NL, Karlson U, Larsen MM, Vangronsveld J, Corbisier P, Csoregi E (2004) Biosensors for detection of mercury in contaminated soils. Environ Pollut 131:255-262

Campbell CD, Hird M, Lumsdon DG, Meeussen JCL (2000) The effect of EDTA and fulvic acid on $\mathrm{Cd}, \mathrm{Zn}$, and $\mathrm{Cu}$ toxicity to a bioluminescent construct (pUCD607) of Escherichia coli. Chemosphere 40: 319-325

Cao XD, Ma LQ, Shiralipour A (2003) Effects of compost and phosphate amendments on arsenic mobility in soils and arsenic uptake by the hyperaccumulator, Pteris vittata L. Environ Pollut 126:157-167

Chirenje T, Ma LQ, Chen M, Zillioux EJ (2003) Comparison between background concentrations of arsenic in urban and non-urban areas of Florida. Adv Environ Res 8:137-146

De Brouwere K, Smolders E, Merckx R (2004) Soil properties affecting solid-liquid distribution of $\mathrm{As}(\mathrm{V})$ in soils. Eur J Soil Sci 55:165-173

Degryse F, Smolders E, Parker DR (2009) Partitioning of metals (Cd, Co, $\mathrm{Cu}, \mathrm{Ni}, \mathrm{Pb}, \mathrm{Zn})$ in soils: concepts, methodologies, prediction and applications - a review. Eur J Soil Sci 60:590-612

Dong WY, Zhang XY, Wang HM, Dai XQ, Sun XM, Qiu WW, Yang FT (2012) Effect of different fertilizer application on the soil fertility of paddy soils in red soil region of southern China. Plos One 7:e44504

Dowdle PR, Laverman AM, Oremland RS (1996) Bacterial dissimilatory reduction of $\operatorname{arsenic}(\mathrm{V})$ to $\operatorname{arsenic}(\mathrm{III})$ in anoxic sediments. Appl Environ Microbiol 62:1664-1669 
Filgueiras AV, Lavilla I, Bendicho C (2002) Chemical sequential extraction for metal partitioning in environmental solid samples. J Environ Monitor 4:823-857

Ge Y, Zhang JB, Zhang LM, Yang M, He JZ (2008) Long-term fertilization regimes affect bacterial community structure and diversity of an agricultural soil in northern China. J Soil Sediment 8:43-50

Giller KE, Witter E, McGrath SP (2009) Heavy metals and soil microbes. Soil Biol Biochem 41:2031-2037

Golding GR, Sparling R, Kelly CA (2008) Effect of pH on intracellular accumulation of trace concentrations of $\mathrm{Hg}$ (II) in Escherichia coli under anaerobic conditions, as measured using a mer-lux bioreporter. Appl Environ Microbiol 74:667-675

Grafe M, Eick MJ, Grossl PR, Saunders AM (2002) Adsorption of arsenate and arsenite on ferrihydrite in the presence and absence of dissolved organic carbon. J Environ Qual 31:1115-1123

Hakkila K, Maksimow M, Karp M, Virta M (2002) Reporter genes lucFF, luxCDABE, gfp, and dsred have different characteristics in wholecell bacterial sensors. Analytical Biochem 301:235-242

Harms H, Wells MC, van der Meer JR (2006) Whole-cell living biosensors - are they ready for environmental application? Appl Microbiol Biotechnol 70:273-280

Harvey CF, Swartz CH, Badruzzaman ABM, Keon-Blute N, Yu W, Ali MA, Jay J, Beckie R, Niedan V, Brabander D, Oates PM, Ashfaque KN, Islam S, Hemond HF, Ahmed MF (2002) Arsenic mobility and groundwater extraction in Bangladesh. Science 298:1602-1606

Hou QH, Ma AZ, Li Y, Zhuang XL, Bai ZH, Zhang XK, Zhuang GQ (2013) Assessing the effect of phosphate and silicate on Cd bioavailability in soil using an Escherichia coli cadAp::luc-based whole-cell sensor. Environ Sci: Process Impact. doi:10.1039/C3EM00598D

Huang JH, Kretzschmar R (2010) Sequential extraction method for speciation of arsenate and arsenite in mineral soils. Anal Chem 82: $5534-5540$

Ivask A, Francois M, Kahru A, Dubourguier HC, Virta M, Douay F (2004) Recombinant luminescent bacterial sensors for the measurement of bioavailability of cadmium and lead in soils polluted by metal smelters. Chemosphere 55:147-156

Ivask A, Green T, Polyak B, Mor A, Kahru A, Virta M, Marks R (2007) Fibre-optic bacterial biosensors and their application for the analysis of bioavailable $\mathrm{Hg}$ and $\mathrm{As}$ in soils and sediments from Aznalcollar mining area in Spain. Biosens Bioelectron 22:1396-1402

Ivask A, Virta M, Kahru A (2002) Construction and use of specific luminescent recombinant bacterial sensors for the assessment of bioavailable fraction of cadmium, zinc, mercury and chromium in the soil. Soil Biol Biochem 34:1439-1447

Jackson BP, Seaman JC, Bertsch PM (2006) Fate of arsenic compounds in poultry litter upon land application. Chemosphere 65:2028-2034

Jain A, Raven KP, Loeppert RH (1999) Arsenite and arsenate adsorption on ferrihydrite: Surface charge reduction and net $\mathrm{OH}-$ release stoichiometry. Environ Sci Technol 33:1179-1184

Kahru A, Ivask A, Kasemets K, Põllumaa L, Kurvet I, Francois M, Dubourguier HC (2005) Biotests and biosensors in ecotoxicological risk assessment of field soils polluted with zinc, lead and cadmium. Environ Toxicol Chem 24:2973-2982

Kalbitz K, Wennrich R (1998) Mobilization of heavy metals and arsenic in polluted wetland soils and its dependence on dissolved organic matter. Sci Total Environ 209:27-39

Lafferty BJ, Loeppert RH (2005) Methyl arsenic adsorption and desorption behavior on iron oxides. Environ Sci Technol 39:2120-2127

Larios R, Fernandez-Martinez R, Rucandio I (2013) Assessment of a sequential extraction procedure for arsenic partitioning and application to samples from different pollution sources. Anal Methods-Uk 5:4096-4104

Li F, Zheng YM, He JZ (2010) Effect of long-term fertilization on total soil arsenic in China. Ann NY Acad Sci 1195:E65-E73

Li YX, Chen TB (2005) Concentrations of additive arsenic in Beijing pig feeds and the residues in pig manure. Resour Conserv Recycl 45:356-367
Liao VHC, Chien MT, Tseng YY, Ou KL (2006) Assessment of heavy metal bioavailability in contaminated sediments and soils using green fluorescent protein-based bacterial biosensors. Environ Pollut 142:17-23

Liao VHC, Ou KL (2005) Development and testing of a green fluorescent protein-based bacterial biosensor for measuring bioavailable arsenic in contaminated groundwater samples. Environ Toxicol Chem 24: 1624-1631

Liu EK, Yan CR, Mei XR, Zhang YQ, Fan TL (2013) Long-term effect of manure and fertilizer on soil organic carbon pools in dryland farming in northwest China. Plos One 8:e56536

Liu PL, Huang QY, Chen WL (2012) Construction and application of a zinc-specific biosensor for assessing the immobilization and bioavailability of zinc in different soils. Environ Pollut 164:66-72

Mladenov N, Zheng Y, Miller MP, Nemergut DR, Legg T, Simone B, Hageman C, Rahman MM, Ahmed KM, McKnight DM (2010) Dissolved organic matter sources and consequences for iron and arsenic mobilization in Bangladesh aquifers. Environ Sci Technol 44:123-128

Naujokas MF, Anderson B, Ahsan H, Aposhian HV, Graziano JH, Thompson C, Suk WA (2013) The broad scope of health effects from chronic arsenic exposure: update on a worldwide public health problem. Environ Health Perspect 121:295-302

Nickson R, McArthur J, Burgess W, Ahmed KM, Ravenscroft P, Rahman M (1998) Arsenic poisoning of Bangladesh groundwater. Nature 395:338

Nolan AL, Lombi E, McLaughlin MJ (2003) Metal bioaccumulation and toxicity in soils - Why bother with speciation? Aust J Chem 56:77-91

Nordstrom DK (2002) Public health-Worldwide occurrences of arsenic in ground water. Science 296:2143-2145

Nybroe O, Brandt KK, Ibrahim YM, Tom-Petersen A, Holm PE (2008) Differential bioavailability of copper complexes to bioluminescent Pseudomonas fluorescens reporter strains. Environ Toxicol Chem 27:2246-2252

Peijnenburg WJGM, Jager T (2003) Monitoring approaches to assess bioaccessibility and bioavailability of metals: Matrix issues. Ecotox Environ Saf 56:63-77

Peijnenburg WJGM, Zablotskaja M, Vijver MG (2007) Monitoring metals in terrestrial environments within a bioavailability framework and a focus on soil extraction. Ecotox Environ Saf 67:163-179

Peltola P, Ivask A, Astrom M, Virta M (2005) Lead and Cu in contaminated urban soils: Extraction with chemical reagents and bioluminescent bacteria and yeast. Sci Total Environ 350:194-203

Petanen T, Romantschuk M (2003) Toxicity and bioavailability to bacteria of particle-associated arsenite and mercury. Chemosphere 50: 409-413

Ramanathan S, Shi WP, Rosen BP, Daunert S (1997) Sensing antimonite and arsenite at the subattomole level with genetically engineered bioluminescent bacteria. Anal Chem 69:3380-3384

Rasmussen LD, Turner RR, Barkay T (1997) Cell-density-dependent sensitivity of a mer-lux bioassay. Appl Environ Microbiol 63: 3291-3293

Rauret G, Lopez-Sanchez JF, Sahuquillo A, Rubio R, Davidson C, Ure A, Quevauviller P (1999) Improvement of the BCR three step sequential extraction procedure prior to the certification of new sediment and soil reference materials. J Environ Monitor 1:57-61

Riether KB, Dollard MA, Billard P (2001) Assessment of heavy metal bioavailability using Escherichia coli zntAp :: lux and copAp :: luxbased biosensors. Appl Microbiol Biotechnol 57:712-716

Sarkar D, Datta R (2003) A modified in-vitro method to assess bioavailable arsenic in pesticide-applied soils. Environ Pollut 126:363-366

Sarkar D, Datta R (2004) Arsenic fate and bioavailability in two soils contaminated with sodium arsenate pesticide: An incubation study. B Environ Contam Tox 72:240-247

Sarkar D, Makris KC, Parra-Noonan MT, Datta R (2007) Effect of soil properties on arsenic fractionation and bioaccessibility in cattle and sheep dipping vat sites. Environ Int 33:164-169 
Signes-Pastor A, Burlo F, Mitra K, Carbonell-Barrachina AA (2007) Arsenic biogeochemistry as affected by phosphorus fertilizer addition, redox potential and $\mathrm{pH}$ in a west Bengal (India) soil. Geoderma 137:504-510

Stocker J, Balluch D, Gsell M, Harms H, Feliciano J, Daunert S, Malik KA, Van der Meer JR (2003) Development of a set of simple bacterial biosensors for quantitative and rapid measurements of arsenite and arsenate in potable water. Environ Sci Technol 37: 4743-4750

Tauriainen S, Karp M, Chang W, Virta M (1998) Luminescent bacterial sensor for cadmium and lead. Biosens Bioelectron 13:931-938

Tibazarwa C, Corbisier P, Mench M, Bossus A, Solda P, Mergeay M, Wyns L, van der Lelie D (2001) A microbial biosensor to predict bioavailable nickel and its transfer to plants. Environ Pollut 113:1926

Toevs GR, Morra MJ, Polizzotto ML, Strawn DG, Bostick BC, Fendorf S (2006) Metal (loid) diagenesis in mine-impacted sediments of Lake Coeur d'Alene, Idaho. Environ Sci Technol 40:2537-2543

Ure AM, Quevauviller P, Muntau H, Griepink B (1993) Speciation of heavy-metals in soils and sediments - an account of the improvement and harmonization of extraction techniques undertaken under the auspices of the Bcr of the Commission-of-the-EuropeanCommunities. Int J Environ an Ch 51:135-151

Van Dorst B, Mehta J, Bekaert K, Rouah-Martin E, De Coen W, Dubruel P, Blust R, Robbens J (2010) Recent advances in recognition elements of food and environmental biosensors: A review. Biosens Bioelectron 26:1178-1194

Van Herreweghe S, Swennen R, Vandecasteele C, Cappuyns V (2003) Solid phase speciation of arsenic by sequential extraction in standard reference materials and industrially contaminated soil samples. Environ Pollut 122:323-342

Wang SL, Mulligan CN (2006) Effect of natural organic matter on arsenic release from soils and sediments into groundwater. Environ Geochem Health 28:197-214

Wenzel WW, Kirchbaumer N, Prohaska T, Stingeder G, Lombi E, Adriano DC (2001) Arsenic fractionation in soils using an improved sequential extraction procedure. Anal Chim Acta 436:309-323

Worms I, Simon DF, Hassler CS, Wilkinson KJ (2006) Bioavailability of trace metals to aquatic microorganisms: importance of chemical, biological and physical processes on biouptake. Biochimie 88: $1721-1731$

Xu W, Wang HJ, Liu RP, Zhao X, Qu JH (2011) Arsenic release from arsenic-bearing Fe-Mn binary oxide: effects of Eh condition. Chemosphere 83:1020-1027

Yang JK, Barnett MO, Jardine PM, Basta NT, Casteel SW (2002) Adsorption, sequestration, and bioaccessibility of $\mathrm{As}(\mathrm{V})$ in soils. Environ Sci Technol 36:4562-4569

Yang XY, Li PR, Zhang SL, Sun BH, Chen XP (2011) Long-termfertilization effects on soil organic carbon, physical properties, and wheat yield of a loess soil. J Plant Nutr Soil Sc 174:775-784

Zhao HS, Stanforth R (2001) Competitive adsorption of phosphate and arsenate on goethite. Environ Sci Technol 35:4753-4757

Zheng Y, Zhang LM, Zheng YM, Di HJ, He JZ (2008a) Abundance and community composition of methanotrophs in a Chinese paddy soil under long-term fertilization practices. J Soil Sediment 8:406-414

Zheng YM, Liu YR, Hu HQ, He JZ (2008b) Mercury in soils of three agricultural experimental stations with long-term fertilization in China. Chemosphere 72:1274-1278 